\title{
Effect of Branded Shoes Price on Perceived Quality
}

\author{
Chen Qiong \\ College of Textiles and Clothing Engineering \\ Soochow University \\ Suzhou, 215123, China
}

\author{
Dr Jiang Xiaofeng \\ (Correspondence Author) \\ College of Textiles and Clothing Engineering \\ Soochow University, Suzhou, 215123, China
}

\begin{abstract}
Price is one of the external clues for consumers' perception to products, studies have revealed that the impact of different categories of product prices on the perceived quality is different. In order to explore the influence of price signals on the perceived quality of brand shoes, six brand shoes were selected as stimuli in this study, and cognitive behavioral test was adopted to allow consumers to perceive the quality of branded shoes marked in high prices and low prices respectively. The results demonstrate that the price of brand shoes has a significant impact on the perceived quality, the perceived quality of highpriced brand shoes is higher than that of low-priced brand shoes ; brand positioning has a significant influence on consumer perception.
\end{abstract}

Keywords-Price; brand; perceived quality; cognitive behavior

\section{INTRODUCTION}

Perceived quality is a subjective evaluation on the quality of the product obtained by the consumer through the acquired product-related information (Wang,2008). It is the subjective judgment based on the external clue of the product rather than the objective attribute of the product (Zeithaml,1988). In the market, many brand companies adopt pricing strategies to affect consumer perception on the quality of their products, to enhance the commercial value of the product. Price, which is considered to be the basis for judging the quality of products, has been confirmed in some studies(Leavitt, 1954; Wang et al,2007;Jacoby et al,1971; Dodds et al,1985), when consumers lack internal product quality cues, as an external attribute, price becomes an important factor to affect consumer's product quality judgment (Gerstner,1985; Johnson et al,1988). The reason why consumers perceive the quality of products relying on external clues is that the potential quality information conveyed by external clues constitutes their cognitive basis for product quality $(\mathrm{Li}, 2008)$.

A large number of studies have shown that there is a positive correlation between price and quality (Dodds et al,1991; Erickson et al,1985; Rao et al,1989; Hu,2016), the higher the price, the better the product quality perceived by consumers. This conclusion comes from a kind of psychological cognition of consumers, that is, high quality products usually require higher production costs than lowquality products (Wang,2011). However, some studies have drawn different conclusions, Gabor survey found that for some cheap or non-durable goods, the price may well be the signal of good quality within the set minimum and maximum price limits, but when prices are above or below this range, product quality will often be considered unreliable (Gabor,1964). Peterson et al. studied the influence of beverage brand, the country of origin and the price on the perceived quality of the product, and found that the effect of brand was more significant, while the effect of price was far less obvious than imagined. Under the influence of two factors, source country and brand, there is a negative correlation between price and perceived quality (Peterson et al,1976). In addition, Parguel et al. conducted research on the price of luxury watches with or without price tagged. The results show that the price signal had no significant impact on the perceived quality of the brand, but had a noteworthy influence on the brand uniqueness (Parguel et al ,2016). In recent years, empirical studies have revealed that the influence of price on perceived quality is declining due to the existence of other factors, such as product category (Ye,2015; Batra et al 2000), the country of origin(Yao,2015; Zhou,2016; Liu,2017), brand (Chen,2018), consumer characteristics. However, a price marked on a moderate range is still an important indicator for consumer to perceive quality of products (Cohen,1988). In this paper, the brand shoes with different popularity and different prices are taken as research objects to explore the influence of brand shoes price on the perceived quality of their products.

\section{EXPERIMENT}

\subsection{Participants}

39 students from Soochow University (age between 18-23, including 5 males and 34 females). The subjects were all righthanded, with no color blindness, weak color, normal vision or rectified vision, and volunteered to participate in the experiment.

\subsection{Stimulus materials}

In this experiment, 11 high-end shoe brands and 12 lowend shoe brands were selected. Using the questionnaire to survey brand familiarity and brand popularity, through analysis, three high-end brands (Nike, Adidas, New Balance), and three low-end brands (Xtep, Anta, Warrior) were selected. Each brand selected five different styles of product images, each of which is processed by Photoshop software to display two kinds of pictures with low price and high price respectively as stimulus materials, and the image size is $100 \mathrm{~mm} \times 140 \mathrm{~mm}$. 


\subsection{Experimental equipment}

This experiment was programmed using E-Prime 2.0 software and run on a computer.

\subsection{Experimental procedure}

A total of 60 stimuli throughout the experiment lasted approximately 6 minutes. Before the formal experiment, 8 stimuli were used for practice. During the experiment, the stimulus was randomly presented in the center of the computer screen through the use of E-Prime software. The distance between the experimental subject and the screen presenting the stimulus was about $70 \mathrm{~cm}$, each stimulus presentation shown in Figure 1

\section{RESULTS AND ANALYSIS}

\subsection{Evaluation of perceived quality}

Analysing the perceived quality scores of the products given by participants when the shoes marked high prices and low prices. The results are shown in Figure 2. The quality score of branded shoes marked with high prices is significantly higher than that of branded shoes with low prices, which is more pronounced in high-end brands. Regardless of the high price or low price, the quality score of high-end brand shoes is always higher than the quality score of low-end brand shoes, indicating that brand positioning will also affect on the perceived quality of products.

To test whether the variables have a significant impact on the perceived quality of the brand shoes, we performed a repetitive measurement analysis of variance. The results are shown in Table 1. The effect of the price factor is significant $(\mathrm{F}=6.878, \mathrm{p}=0.012)$, suggesting that the price has a significant impact on the quality evaluation of the shoes; the main effect of the brand positioning factor is also significant $(\mathrm{F}=41.866$, $\mathrm{p}=0.000$ ), indicating that the brand positioning affects the perceived quality of the shoes; price and brand positioning interaction effect is marginal significant $(\mathrm{F}=4.049, \mathrm{p}=0.051)$, compared with low-end brand shoes, high-end brand shoes marked higher price have higher perceived quality.

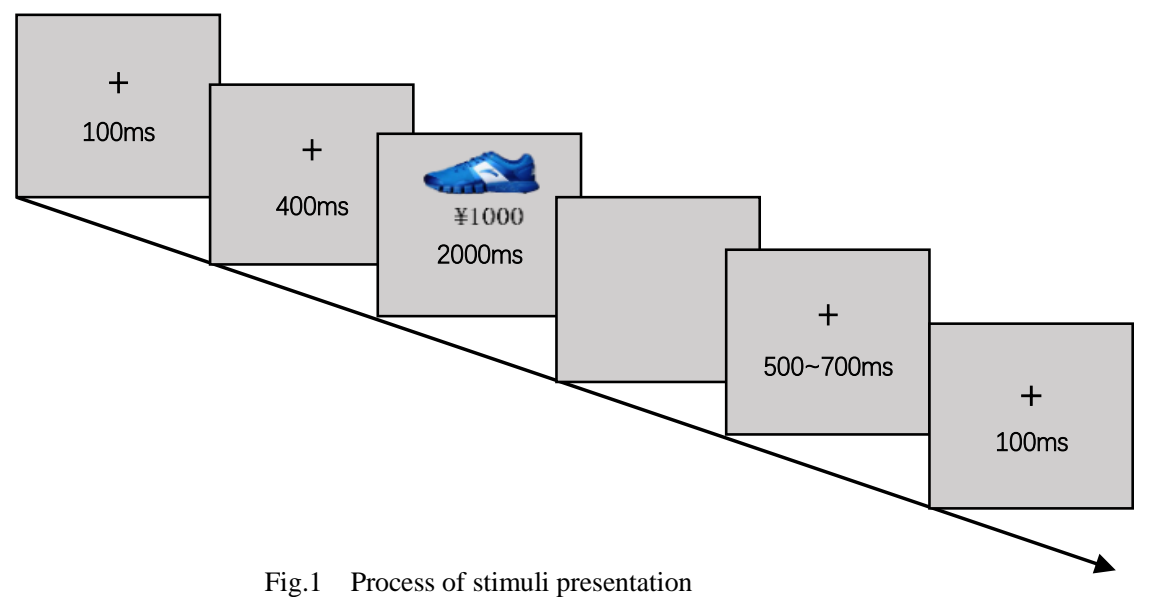

Fig.1 Process of stimuli presentation

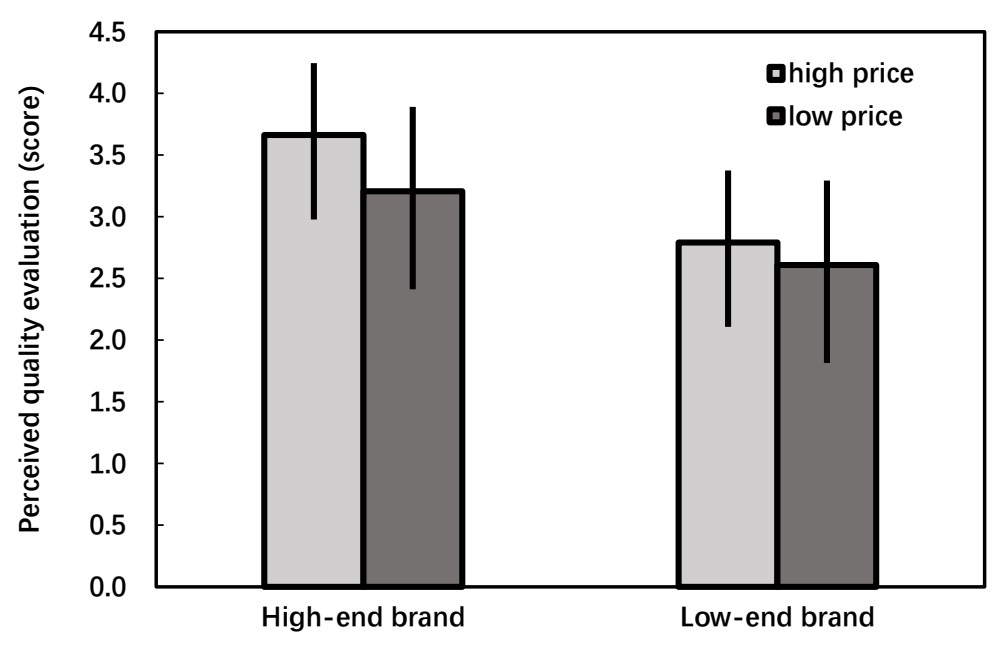

Fig.2 Evaluation of perceived quality on brand 
Tab.1 Variance analysis table for quality perception evaluation on brand shoes

\begin{tabular}{|c|c|c|c|c|c|}
\hline Source & Type III sum of squares & Mean square & df & Sig. & Partial Eta squared \\
\hline Price & 3.978 & 3.978 & 6.878 & $0.012 *$ & 0.153 \\
\hline Brand Positioning & 21.006 & 21.006 & 41.866 & $0.000 * *$ & 0.524 \\
\hline Price $\times$ Brand Positioning & 0.726 & 0.726 & 4.049 & 0.051 & 0.096 \\
\hline
\end{tabular}

Note: * indicates a significant correlation at the 0.05 level; ** indicates a significant correlation at the 0.01 level.

\subsection{Response time of quality perception}

Figure 3 is the reaction time for consumer perceived quality. As can be seen from the figure, the time for evaluating branded shoes with high prices is higher than the time for evaluating branded shoes with low prices, and the gap between the low-end brand shoes is more obvious. Repeated measures analysis of variance analysis showed that the price had a significant effect on reaction time $(\mathrm{F}=11.803, \mathrm{p}=0.001)$, suggesting that there were significant differences in perceived quality judgment time under different price labels, while the reaction time of brand positioning had no significant main effect. The interaction effect of reaction time between price and brand positioning is not significant, as shown in Table 2 .

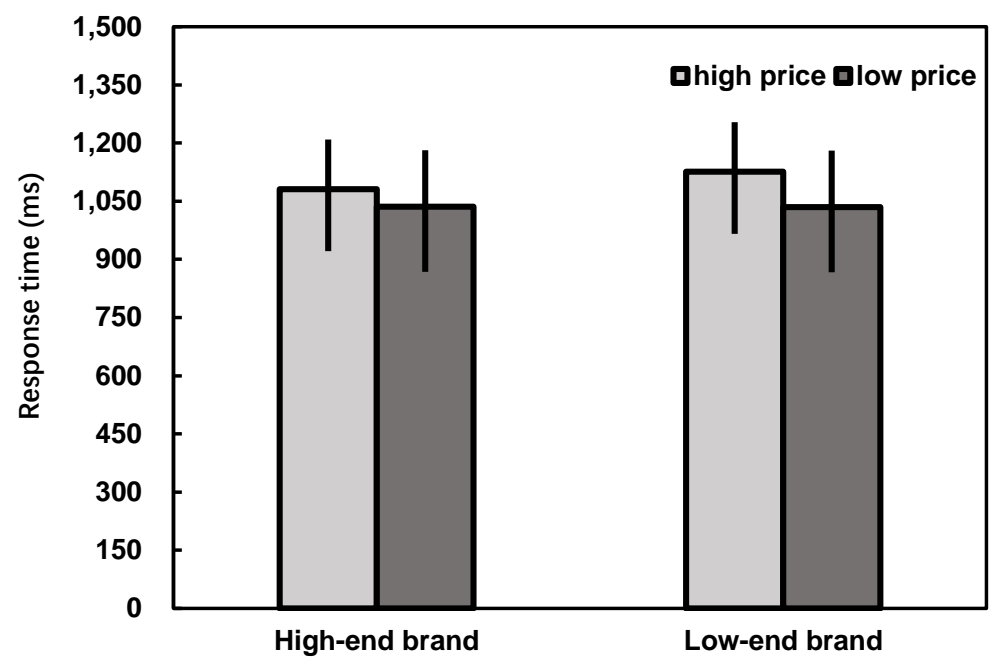

Fig.3 Response time

Tab.2 Variance analysis table for response time of quality perception on brand shoes

\begin{tabular}{llcrrr}
\hline Source & Type III sum of squares & Mean square & df & Sig. & Partial Eta squared \\
\hline Price & 181007.557 & 181007.557 & 11.803 & $0.001 * *$ & 0.237 \\
Brand Positioning & 18534.360 & 18534.360 & 2.057 & 0.160 & 0.051 \\
Price $\times$ Brand Positioning & 20395.542 & 20395.542 & 3.385 & 0.074 & 0.082 \\
\hline
\end{tabular}

Note: $*$ indicates a significant correlation at the 0.05 level; ** indicates a significant correlation at the 0.01 level

\section{CONCLUSION}

In the present research, we transferred the research perspective from a broad product to a specific brand shoes, exploring the impact of branded shoes price and brand positioning on consumer perceived quality. Through the analysis of behavioral experimental data, it is found that price has a significant influence in the judgment-making process of perception quality. This shows that the subject is susceptible to be influenced by the price clues in the quality perception evaluation, because the consumer can use price cues to generate quality association, the higher the price marked, the better the perceived quality of the shoes; in addition, the brand positioning has a moderating effect on the perceived quality. Under the same brand positioning, the price of brand shoes is significantly positively correlated with the perceived quality. but when the brand positioning is different, the price marked 
on the brand shoes is the same, compared with the lower-end brand, the perceived quality of the high-end product is significantly higher than that at the same price.

Results of this exploratory study should help the brand shoe company to better understand the consumer's product perceptions and provide theoretical support for the firms to develop relevant marketing strategies.

\section{REFERENCES}

[1] Batra R, Ramaswamy V, Alden D L, et al. Effects of brand local and nonlocal origin on consumer attitudes in developing countries[J]. Journal of consumer psychology, 2000, 9(2): 83-95.

[2] CHEN Qianyun. Effect of brand loges on consumer perception for women's Dress [D]. Soochow University, 2018.

[3] Cohen J. Statistical Power Analysis in the Behaviour Sciences New Jersey[J]. Lawrence Erbarum Asssociates Inc, 1988.

[4] Dodds W B, Monroe K B, Grewal D. Effects of price, brand, and store information on buyers' product evaluations[J]. Journal of marketing research, 1991, 28(3): 307-319.

[5] Dodds, W. B. \& Monroe, K. B. The effect of brand and price information on subjective product evaluations[J]. Advances in consumer research, 1985, 12 (1):85-90

[6] Erickson G M, Johansson J K. The role of price in multi-attribute product evaluations[J]. Journal of consumer research, 1985, 12(2): 195-199.

[7] Gabor A. Price sensitivity of the consumer [J]. J. Advertising Res., 1964, 4(4): 40-44.

[8] Gerstner E. Do higher prices signal higher quality?[J]. Journal of marketing research, 1985, 22(2): 209-215.

[9] HU Hao. Research towards the effect of extrinsic cues on customer perceived quality and purchase intention_ a case of packaged tea [D]. South China Agricultural University, 2016.

[10] Jacoby J, Olson J C, Haddock R A. Price, brand name, and product composition characteristics as determinants of perceived quality[J]. Journal of Applied Psychology, 1971, 55(6): 570.

[11] Johnson R L, Kellaris J J. An exploratory study of price/perceivedquality relationships among consumer services[J]. ACR North American Advances, 1988.

[12] Leavitt H J. A note on some experimental findings about the meanings of price[J]. The Journal of Business, 1954, 27: 205-205.

[13] LI Jingwei. An Empirical Study on the effects of perceived quality of private brand on store image [D]. Jilin University, 2008.

[14] LIU Yadan. An Empirical Study of Consumer Cosmetics Brand Preference and Purchasing Behavior-Based on Comparison between Thai Brands and Local Brands [D]. Yunnan University of Finance and Economics, 2017.

[15] Parguel B, Delécolle T, Valette-Florence P. How price display influences consumer luxury perceptions[J]. Journal of Business Research, 2016, 69(1): 341-348.

[16] Peterson R A, Jolibert A J. A cross-national investigation of price and brand as determinants of perceived product quality[J]. Journal of Applied Psychology, 1976, 61(4): 533.

[17] Rao A R, Monroe K B. The effect of price, brand name, and store name on buyers' perceptions of product quality: An integrative review[J]. Journal of marketing Research, 1989, 26(3): 351-357.

[18] WANG Baolu. Analysis of the influence of consumer perception and the text logo of women's fashion brand [D]. Beijing Institute Of Fashion Technology, 2011.
[19] WANG Haizhong, Wang Jingxue, He Yun. The suggestive effect of brand name, country of origin and price on perceived quality and purchase intention [J]. Nankai Management Review, 2007, No.5706:19-25+32.

[20] WANG Lu. Brand extension effection evaluation with brand image [D]. Xi'an University of Science and Technology, 2008.

[21] YAO Lulu. A study on international comparison of product perceived quality and its relationship with the country-of-origin image [D]. Huazhong University of Science and Technology, 2015.

[22] YE Mengjie. Study on the Influence of Consumer Perceived Quality Difference on Purchase Behavior-Taking Handmade Products and Industrial Products as Examples[D]. Capital University of Economics and Business, 2015.

[23] Zeithaml V A. Consumer perceptions of price, quality, and value: a means-end model and synthesis of evidence[J]. Journal of marketing, 1988, 52(3): 2-22.

[24] ZHOU Bing. Research on the purchasing behavior differences between the products from different countries of origin with the same brand for Chinese consumers [D]. Xiangtan University, 2016. 